\title{
An Analysis of Basic Skills Teaching the Biology Pre- Service Teachers Based on Model Core Teaching Standards in PLP Program at an Islamic University in Jakarta
}

\author{
Sujiyo Miranto \\ \{sujiyo@uinjkt.ac.id \} \\ UIN Syarif Hidayatullah Jakarta, Indonesia
}

\begin{abstract}
Basic teaching skills are needed by teachers in learning. The PPL II program was designed to introduce students to real teacher assignments. The research problem of this research is how the basic skills of student teaching are in the perspective of the supervisor, while the research objective is to find out the basic skills of teaching students in the PPL II Program. This is a descriptive research with a quantitative approach. The samples of this study sample were 6 PLP II program supervisors. The research technique used is direct observation in learning activities and direct communication with the supervisors. The data were collected by using observation sheets and instruments about core teaching standards consisting of 9 standards: (1) the skills of developing learning scenarios, (2) the skills of opening lessons, (3) the skills of explaining, (4) the skills of asking questions, (5) the skills of managing learning, (6) the skills of developing variations, (7) the skills of using instructional media, (8) the skills of providing reinforcement, (9) the skills of closing the learning. The research conclusions are: (1) the lowest skill with a good category is explaining skills of $71.77 \%$. (2) the highest skill with a very good category is the skill to use learning media at $79.58 \%$. Overall the basic skills of teaching students have good criteria.The PPL (Profesi Pengenalan Lapangan -teaching practice) II is an apprenticeship program for students majoring at teacher training department. This study aims to identify whether or not the students who were in the PPL II program have acquired the Basic Skill namely, (1) the skills of developing learning scenarios, (2) the skills of opening lessons, (3) the skills of explaining, (4) the skills of asking questions, (5) the skills of managing learning, (6) the skills of developing variations, (7) the skills of using instructional media, (8) the skills of providing reinforcement, (9) the skills of closing the learning. . This study quantitative descriptive study involved 6 teachers who supervised students at the PPL II program. Drawing on data from classroom observations and interviews, the study revealed that students at the PPL II program have an excellent competence in using learning media, but they need to enhance their in terms of explaining learning material.
\end{abstract}

Keywords: Basic Teaching Skills, Core Teaching Standards.

\section{Introduction}

Basic teaching skills are very important and needed by prospective Biology teachers to carry out good learning. Teaching success is determined by some factors such as ability, motivation, student activity, completeness of learning facilities and learning environment, 
which is also influenced by the ability of teachers to develop various teaching skills [1]. One way that can be done to improve the teaching skills of prospective biology teachers is by practicing direct learning in schools. Each educational institution has a different way of preparing prospective teachers to be skilled in managing learning.

The Biology Education Study Program UIN Syarif Hidayatullah Jakarta has a School Environment Practice (PLP) course, which aims to prepare, foster, and improve the quality of graduate teacher candidates who meet the teacher's professional standards. The basic teaching skills that teachers have can be used to carry out tasks according to their competencies so they can be used to develop students' potential[2].

At present, there are no data available about the basic skills of teaching students after taking these activities (PLP). The unavailability of these data causes the unknown success of learning programs related to the basic skills of teaching prospective teachers after participating in this PLP activity. Therefore, researchers are interested in examining the basic teaching skills of prospective Biology teachers who have participated in the PLP Program according to the perception of the supervisor.

Biology education students as prospective biology teachers still need guidance to possess knowledge and pedagogical skills in science content [3], [4] Meanwhile research conducted by Nurjahni et al. (2012) proves that aspects of teaching skills that are still low in prospective biology teachers are aspects of determining the appropriate form of assessments and compiling their rubrics [5]. Research by Nurasiah and Supriatno (2015) found that although biology teacher candidates already have the ability to plan and implement learning, skills in conducting assessments still need to be improved [6]. Husnawati's research (2014) shows that only a small proportion of prospective biology teachers are able to give appropriate questions and have good questioning techniques [6]. The results of these studies indicate that the education of prospective teachers still needs to be improved, because the quality of teachers is closely related to student's achievement [6].

Teaching skills are the ability to specify performance goals, diagnose students, choose teaching strategies, interact with students and assess the effectiveness of teaching [7]. Basic teaching skills consist of explaining skills, asking questions, using variations, giving reinforcement skills, opening and closing lessons, small and individual group teaching skills, class management skills, and discussion guidance skills [1], [8].

The Council of Chief State School Officers (2010) states that in order to find out the teaching skills of prospective teachers who are professional in teaching, a core teaching standard model is found which is the development of the microteaching model. This model emphasizes more on three aspects, namely: performance, knowledge and disposition that must be possessed by the teacher [9]. This research is the first step to identify the basic skills of teaching of biology teacher candidates and efforts to overcome the problems encountered by biology teacher candidates in PLP activities.

\section{Methodology}

This type of research is a qualitative research study to analyze the perspective of PLP supervisor on the basic skills of teaching of prospective Biology teachers which consists of aspects of composing learning scenarios, opening skills, explaining skills, asking skills, managing the learning process, creating variety skills, using instructional media, providing reinforcement, and closing the learning.

Based on the indicators of basic teaching skills, it is then developed the learning assessment rubric. The data obtained from the assessment rubric filled by lecturers and 
supervisors by giving a score of 1 to 4 with a value of 1 (very unskilled), 2 (unskilled), 3 (skilled), and 4 (very skilled). The quantitative data obtained were analyzed to see the level of basic teaching skills of the prospective biology teachers.

The sampling technique used purposive sampling. The research locations are 6 (six) partner schools in the South Tangerang area where PLP activities are carried out. The research subjects were 60 prospective biology teacher participants in PLP 2019. To find out the perceptions of supervisors regarding the basic teaching skills of students, the data were collected through a questionnaire given to 6 supervisors and 6 tutors to provide feedback on the basic teaching skills.

Data validation is done by using two types of triangulation, namely: first, the triangulation of data sources in the form of information from places, events and documents containing notes related to the intended data and secondly, triangulation of techniques or methods of data collection derived from interviews, observations, and document. The data were analyzed by qualitative descriptive by describing and presenting all problems. The data analysis in this study used the steps of the Mills and Huberman model, namely data reduction, data display, and verification.

\section{Result and Discussion}

\subsection{Skills of Developing Learning Scenarios}

The skill of developing learning scenarios is a skill that aims to arrange the steps of learning activities. The basic skills of teaching prospective biology teachers if analyzed from the aspects of the skills to compile a learning scenario included into good criteria (76.04\%). The results of this study are in accordance with the study of theories that have been presented previously, that the skills of developing learning scenarios will determine success in learning. It also means that the prospective biology teachers had the skills to prepare learning scenarios with a variety of strategies and techniques in learning. With this ability, the prospective biology teachers have been able to choose what technique which was most appropriate related to the psychological development of students and the level of material difficulty faced [10]. But there were still $23.06 \%$ of the teacher candidates who had not mastered this skill or had in a less skilled condition.

\subsection{Skills of Opening the Lessons}

The skills indicator of opening the lesson in this study which was observed consisted of skills to provide motivation, skills to attract the attention of students and the skills to do apperception. The skills to provide motivation were categorized as unskilled conditions $(16.67 \%)$, skilled conditions $(65 \%)$ and very skilled $(8.33 \%)$. While the skills indicators attracting the attention of students obtained the data as unskilled data (21.67\%), skilled (58.33) and very skilled $(20.05 \%)$. Apperception skills obtained data of prospective biology teacher as already skilled $(16.67 \%)$, skilled $(75 \%)$ and very skilled $(8.3 \%)$ in doing apperception.

With these conditions, the prospective biology teachers had different skills in opening the lessons. Some ways that were done were checking the attendance of the students and the readiness of students, and asking about the conditions of the students. As for the indicator of apperception, it was conducted by discussion, focusing students' attention and giving students assignments.

\subsection{The Skills of Explaining}


The skills of prospective biology teachers in explaining the lesson were in good criteria $(71.77 \%)$. When explaining, the prospective teachers did the explaining skills systematically. They were able to provide illustrations with simple drawings so the students could easily understand the lesson. The prospective biology teachers were also able to relate the lesson to the daily lives of the students. The quality of the lessons described by the prospective teachers had good qualifications.

When explaining, the teacher candidates did emphasis on certain parts to focus the attention of the students. The skills of explaining of the prospective biology teachers on the indicators of the ability to express and avoid unnecessary words are obtained by unskilled data $(21.67 \%)$, skilled $(58.33 \%)$ and very skilled $(20.00 \%)$. The indicator of skills in compiling sentences that were easy to understand is obtained as unskilled data $(26.67 \%)$, skilled $(56.67 \%)$ and very skilled $(16.67 \%)$.

For indicators of skills of avoiding dubious terms the data showed as unskilled $(25.00 \%)$, skilled $(58.33 \%)$ and highly skilled $(16.67 \%)$. For indicators of clarity of sound the data indicated as unskilled $(30.00 \%)$, skilled $(30.00 \%)$ and highly skilled $(13.33 \%)$. The results of this study are in accordance with the opinion of Marno and Idris (2014) that states when explaining, teachers must provide opportunities for students to explain their level of understanding. This explaining skill will have an impact on more directed learning activities in accordance with the expected competencies.

\subsection{The Skills of Asking Questioning}

Questioning skills are one of the competencies that the prospective teachers must have. From the data. it was obtained that questioning skills were categorized as the unskilled $(8.33 \%)$, skilled $(81.67 \%)$ and very skilled accounted for $10.00 \%$. The indicator of paying attention to the lag time of the students in delivering answers showed percentage of unskilled $(18.33 \%)$, skilled $(75.00 \%)$ and very skilled $(6.67 \%)$. The indicator of giving feedback after the questions are answered indicated as in the unskilled $(21.67 \%)$, skilled $(71.67 \%)$ and very skilled $(6.67 \%)$ categories.

Questioning skills are needed to provide stimulus to the students to comment and perceive students' understanding. Questions addressed to the students are not always easy or difficult but must vary. Overall, the skills to ask for the prospective biology teachers are in the good category $(73.47 \%)$. The results of the observation found that the prospective biology teacher still had difficulty in asking questions due to the lack of technical ability to ask questions. The ability to ask is the ability that will develop along with students' teaching experience. The distribution of questioning skills in learning is uneven, hence, the prospective teachers tended to ask certain students who were considered to be able to respond.

\subsection{The Skills of Managing the Learning}

Managing learning is an attempt by the teacher to understand the condition the classroom atmosphere in order to create an optimal learning climate to support the success of learning. These skills are some things the teachers must master in order to be able to manage the learning; understand the characteristics of students, master the material, master the strategy, understand how to divide the attention to students, manage learning activities in groups, and solve problems encountered during the learning process [11].

The skills to manage learning in term of the indicators of presenting teaching materials that are relevant to the learning objectives are in the unskilled $(15.00 \%)$, skilled $(15.00 \%)$ and very skilled $(18.33 \%)$ categories. Skill in managing learning for the indicators of enthusiasm in 
learning activities are in the category of unskilled (15.00\%), skilled (63.33\%) and very skilled $(21.67 \%)$.

\subsection{The Skills of Developing Variation}

Variation skills in learning belongs to skilled categories. This conclusion is based on the results of the analysis of data trends shown in the indicators of variation in the use of instructional media in the category of unskilled (30.00\%), skilled $(51.67 \%)$ and highly skilled $(18.33 \%)$. For indicators of sound variations, eye contacts, body movements, and expressions are in the category of unskilled $(23.33 \%)$, skilled (58.33\%) and very skilled $(18.33 \%)$.

The results of this study are in accordance with the theoretical studies described previously. Variations made by the teacher in learning such as variations in language, movement, appearance, and media will affect learning. This is because the various types of variations developed will increase the enthusiasm of students who have $s$ an impact on increasing students' understanding.

The variations made by the teacher will convince and encourage the seriousness of students in participating in learning [11].

\subsection{The Skills of Using Instructional Media}

Learning media are important parts of the learning process which must be considered in learning to facilitate students in learning. The skills of using instructional media are in the unskilled $(11.67 \%)$, skilled $(58.33 \%)$ and very skilled categories $(30.00 \%)$. The recapitulation results of closing the lessons showed good result that was equal to $73.47 \%$. Observation results proved that the prospective teachers invited the tudents to make learning conclusions. Each prospective biology teacher has a different way of guiding students to conclude the learning.

There are prospective teachers who concluded the learning by guiding the students to provide arguments about the lessons they have learned. In such way, the teachers could find out whether the students have understood the lessons delivered. While other teacher candidates formulated conclusions by giving notes to the students to be developed into a sentence

\subsection{The Skills of Providing Reinforcement}

Strengthening is the teacher's activity to increase the motivation of students to be more active in learning. The skills to provide reinforcement for indicators showed good attitude and attractive facial expressions when giving reinforcement which were the unskilled $(6.67 \%)$, skilled $(80.00 \%)$ and very skilled $(13.33 \%)$ categories. The skills of strengthening for indicators in which the strengthening was given according to the ability of students belonged to the category of unskilled $(21.67 \%)$, skilled $(68.33 \%)$ and very skilled $(10.00 \%)$. The skills indicators provides reinforcement of material that is important to be mastered by students. This skills are in the category of unskilled $(20.00 \%)$, skilled $(70.00 \%)$ and very skilled $(10.00 \%)$. The intended reinforcement is a positive response from the prospective teachers to the students during the learning process.

Provision of reinforcement is generally conducted by the prospective teachers with the aim that students were more actively participating in learning interactions and repeating good behavior. Most biology teacher candidates are already skillful in providing reinforcement in learning through verbal and nonverbal reinforcement, $t$ intonation and voice clarity, providing opportunities for students to think, and mobility when teaching. However, the prospective 
students who were in the less skilled category felt nervous when teaching that sometimes disturbed students' attention, such as scratching their heads, tidying clothes, eyes that are less focused on the students.

\subsection{The Skills of Closing the Learning}

The skills of closing the learning for the indicators of reviewing the lessons learned showed the following percentages unskilled (16.67\%), skilled $(78.33 \%)$ and very skilled $(5.00 \%)$ categories. For the indicators of summarizing the learning the category showed of the following: unskilled (11.67\%), skilled (81.67\%) and very skilled $(6.67 \%)$. In addition, the indicators of skills of informing further lessons in the category of unskilled $(18.33 \%)$, skilled $(68.33 \%)$ and very skilled $(13.33 \%)$. The recapitulation results of the skills of closing the lessons are in good state that is equal to $73.47 \%$. The observation results proved that the prospective teachers invited students to make learning conclusions. Each prospective biology teacher has a different way of guiding students to conclude the learning.

There are prospective teachers who conclude the learning by guiding the students to provide arguments about lessons they have learned. In this way, the teacher can find out whether the students have understood the lessons delivered or not. While other teacher candidates formulated the conclusions by giving notes to the students to be developed into a sentence.

\section{Conclusion}

Research conclusion (1) the lowest skill with a good category is the explaining skills which was $71.77 \%$. (2) the highest skill with a very good category is the skill of using learning media at $79.58 \%$. Overall, the basic skills of teaching students have good criteria.

Acknowledgements. The authors thank the headmasters of partner schools, tutor teachers and supervisors who have supported this research activity.

\section{References}

[1] M. R. D. Wahyulestari, "Keterampilan Dasar Mengajar di Sekolah Dasar," in Prosiding Seminar Nasional Pendidikan Era Revolusi, 2018, pp. 199-210.

[2] K. Munandar, "Pembelajaran praktikum berbasis inkuiri MPPBI-PPI untuk meningkatkan kompetensi calon guru biologi," J. Biol. dan Pembelajaran Biol., vol. 2, no. 1, pp. 91-100, 2017.

[3] S. Anggraeni, "Sudahkah Calon Guru Biologi Merencanakan Pembelajaran Biologi yang Sesuai dengan Hakekat Sains?," in Prosiding Seminar Nasional Penelitian, Pendidikan dan Penerapan MIPA, 2009, pp. 340-348.

[4] K. Munandar, "Infrastruktur Laboratorium Biologi Di SMA Jember Sebagai Penunjang Pembelajaran," BIOMA J. Keilmuan dan Kependidikan MIPA, vol. 8, no. 1, pp. 74-89, 2013.

[5] M. Nurjhani, N. Y. Rustaman, and S. Redjeki, "Relevansi Keterampilan Mengajar Calon Guru Biologi Dengan Penguasaan Konsep Gizi," in Prosiding Seminar Nasional IX Pendidikan Biologi FKIP UNS, 2012, pp. 360-365.

[6] P. Nurasiah and B. Supriatno, "Analisis Kinerja Mengajar Calon Guru Biologi pada Kegiatan Pembelajaran Biologi di SMA Negeri Kota Bandung," in Prosiding Simposium Nasional Inovasi dan Pembelajaran Sains 2015, 2015, pp. 485-488. 
[7] N. S. Sukmadinata, Metode Penelitian Pendidikan. Bandung: PT Remaja Rosdakarya, 2012.

[8] A. Majid, Strategi Pembelajaran. Bandung: Remaja Rosda Karya, 2013.

[9] R. Rusninawiyah, T. Kurniati, and R. A. Kurniawan, "Analisis Ketrampilan Dasar Mengajar Mahasiswa Calon Guru Kimia Berbasis Model Core Teaching Standards Pada Mata Kuliah Micro Teaching," Ar-Razi J. Ilm., vol. 6, no. 1, pp. 109-122, 2018.

[10] M. Cara and M. Yang, "Pentingnya Memahami Perkembangan Anak Untuk," Pancawahana J. Stud. Islam, vol. 12, no. 1, pp. 1-9, 2017.

[11] F. Wijarini and S. Ilma, "The Analysis of Teacher Candidates' Teaching Skill in Department of Biology Education, University of Borneo Tarakan, Through Preservice Teaching Activities," J. Pendidik. Biol. Indones., vol. 3, no. 2, pp. 149-159, 2017. 